Archived version from NCDOCKS Institutional Repository http://libres.uncg.edu/ir/asu/

\title{
Appalacȟnan
}

B O O NE, NORTH CAROLINA

\section{Picturing Pleasure: \\ Fanny Stevenson and Beatrice Grimshaw in the Pacific Islands}

\author{
By: Heather Waldroup
}

\begin{abstract}
This article explores the travel writings, illustrated with photographs, of Fanny Stevenson and Beatrice Grimshaw, two 'lady travelers' who visited the Pacific Islands at the turn of the twentieth century. Although little critical attention has been paid to their books, these texts are significant contributions to the comparatively small archive ofEuro-American women's narratives of travel and encounter in the Pacific Islands from this period. Their representations of the Islands are at once conventional and unusual, and analysis of their texts adds significantly to the literature on women's travel writing, especially as the Pacific Islands are an underrepresented area in this field. Rather than producing generalized exoticist representations, their discussions of class, race, gender, and colonial politics are particular to the Pacific Islands, and illustrate various moments of contact at a key transition point in Pacific colonial history. Their use of photographs also forges a strong connection between their work and a longer history of image production by Westerners in the Pacific Islands. Using colonial history as a framework for exploration of class, race, and gender politics in the Pacific Islands, this essay argues that Stevenson and Grimshaw's works suggest ways that popular audiences may have experienced the Pacific Islands through word and image publications.
\end{abstract}

Waldroup, Heather. (2009). "Picturing Pleasure: Fanny Stevenson and Beatrice Grimshaw in the Pacific Islands". Women’s History Review 18:1, 1-22 (lead essay). Version of record Available At Taylor \& Francis 
We all don the clothes of civilization to go on ashore, looking very strange to each other. (Fanny Stevenson, The Cruise of the 'Janet Nichol')

At the turn of the twentieth century, Fanny Van de Grift Stevenson and Beatrice Grimshaw traveled through the South Pacific on steamships, visiting various archipelagos and recording their travels in popular books illustrated with photographs. Stevenson's meandering voyage of 1890 was memorialized with the publication of The Cruise of the 'Janet Nichol' Among the South Sea Islands: A Diary by Mrs. Robert Louis Stevenson in 1914. Grimshaw recorded her 1905 journey from Tahiti Nui to New Zealand in her book, In the Strange South Seas, first published in 1907.[1]Grimshaw, a British journalist, traveled by herself, while Stevenson traveled with her well-known husband, Robert Louis Stevenson, and her adult son, Lloyd Osbourne. While Grimshaw's book was fairly popular upon publication, Stevenson's was not widely read at the time, and there is little contemporary critical analysis of either work. Nevertheless, their illustrated books shed extensive light on the political and social theater of the Pacific Islands at a key moment in both Island and Western colonial history. Both books speak to the continued importance of the image in marketing the eastern and central Pacific Islands as potential destination for travel or settlement, and their combination of text and photographs also heightened the experience of their readers, particularly as the truth value of photographs remained (relatively) in place in the early twentieth century. The two texts also add significantly to the current discourse on women's travel writings in both Pacific and global contexts. Altogether, a comparison of their texts suggests ways British and American women may have experienced the Pacific Islands, both as authors/image-makers and as readers/viewers. Stevenson's and Grimshaw's books emerge from a primarily male-authored archive to reveal that the construction of the Pacific Islands by and for anglophone women at the beginning of the twentieth century was unstable and shifting, intersecting with discourses of race, class, gender, and colonialism in complex ways.

Although Stevenson and Grimshaw are part of a small group of women travelers to the Pacific who recorded their accounts, their texts are not distinctive solely because they are written by women, and I do not juxtapose their works here in order to suggest an essential category of 'women travelers' for which Stevenson and Grimshaw stand as universal subjects.[2] Both do to an extent represent a certain turn-of-the-century type, the independent and mobile woman, relatively middle class and traveling in comfort, yet intrigued by the prospect of adventure and often in the service of a broader project, such as missionization or scientific exploration. Mary Kingsley's records of her work as a zoological specimen collector in Africa are key examples in a broader geographical context. Several of these 'lady travelers' coursed their way through the Pacific during the late nineteenth century and recorded their journeys. Constance Gordon Cumming's A Lady's Cruise on a French Man-of-War (1882) and Isabella Bird's The Hawaiian Archipelago: six months among the palm groves, coral reefs and volcanoes of the Sandwich Islands (1882) were particularly well-known travel writings in English from the Pacific.[3] Gordon Cumming also illustrated her work with sketches that are intriguing if picturesque and conventional. These works and those of Stevenson and Grimshaw draw on some of the same iconic imagery as those of their male equivalents: Indigenous women draped in vegetation, villagers posing in ordered rows, men performing active labor in service of the imperial project. 
Stevenson's and Grimshaw's works are nevertheless distinct for a number of reasons. They are conventional in their relationship to the history of Western representations of the Pacific in the way the experiences of both women are marked by a certain reorientation, a sublime longing for intimate and eroticized (though not necessarily sexualized) physical encounter with Islanders. This relationship certainly posits a reexamination of the notion of the 'male gaze' as it plays out in the colonial sphere. Their publications also suggest the discursive nature of experiences of encounter between the various actors in the Pacific at the turn of the last century. At this point in Island history, 'encounter' was an especially complex fabric of experience that played out on multiple levels of social and racial hierarchy, amongst Islanders and Westerners alike. Stevenson and Grimshaw discuss ambiguous social actors such as Indigenous missionaries, displaced indentured Indigenous laborers, ostracized European beachcombers, and isolated and overworked mission wives. Both Britain and the USA had clearly defined colonial interests in the Pacific at the time of the two works' publication, which I will discuss in greater specificity below, and while the national identities of both authors are somewhat shifting, Stevenson and Grimshaw are nevertheless key figures within the construction of these colonized spaces. Their works, although problematic and probably at least partially fictionalized, make important contributions to the archive of representation of the Pacific by the West, and are firmly located within the history of representation of this contact. Further, much of the extant scholarship on travel writing in the Pacific focuses on writings by men. An analysis of women's contributions to this genre opens up further consideration of the role of gender in colonial contact, and the intersectional gaze directed by white women at their Pacific Island subjects.

What marks their texts as additionally singular is the combination of a more typical style of travel writing with the most significant of modernity's image-making technologies, the photograph. Developments in late nineteenth-century photography, including shortened exposure times, portable cameras, the use of the negative, and the photogravure printing process, enabled Stevenson's and Grimshaw's use of the camera during their Pacific travels and the printing of photographic illustrations in their books. This is not to say that Stevenson and Grimshaw are 'photographers' in the same way that they are the authors of their written texts; indeed, it can be difficult to determine who actually pressed the shutter for the photographs published in either text. As Roslyn Jolly notes, Stevenson was probably not the photographer for many of the images appearing in The Cruise of the 'Janet Nichol'; more likely, the actual camera operator was Stevenson's adult son, Lloyd Osbourne.[4] Similarly, the photographs in Grimshaw's text are difficult to attribute; the only photo credit in the text notes that the illustrations are 'principally from the author's photographs'.[5] What interests me more for the purposes of this essay is the choice of photographs, from what was certainly a larger body of work, to appear in publication, the combination of text and photograph that appears in these publications, the interworkings of the two languages, and just as often, the disjuncture between the two. Considering the particular importance of photography in marketing the Pacific since the late nineteenth century, as texts illustrated with photographs Stevenson's and Grimshaw's publications are part of the modern(ist) archive of the representation of the Pacific.[6] I am also interested in the ways the photographs would have produced a particular kind of experience for the readers of these texts that would not have been possible with, for example, the sketches accompanying Gordon Cumming's writings.[7] 
The Pacific Islands had captured the interest of anglophone audiences through words and pictures since the publication of the illustrated narratives of Captain James Cook's first voyage in 1771 in Britain and soon thereafter in North America. From the earliest sustained encounters between Islanders and Europeans in the 1760s, the islands of the central and eastern Pacific were cast by the West as a beautiful place inhabited by beautiful people. As products of the early twentieth century, the works of Stevenson and Grimshaw are singularly modern creations that exhibit a clear shift from their nineteenth-century counterparts. Grimshaw's account reinscribes a typically colonialist gaze, while the complicated racial and class mixing that Stevenson purports to enjoy reveals a particularly American experience in the Pacific. A comparative analysis of their texts invites further questioning of the distinctions between the particular discursive productions of British and American women writing, imaging, and experiencing the Pacific Islands.

\section{WOMEN, TRAVEL, AND THE COLONIAL REALM}

As Kristi Segal argues of women's travel writing, 'gender matters, but it matters in a way that is irreducibly complex'.[8] In addition to their intriguing use of photographs, Grimshaw's and Stevenson's unique engagement with the genre of travel writing, and the complex intersectional gaze such writing enables, requires a consideration of their works within the critical discussions of gender, travel, and imperialism. Mary Louise Pratt, Sara Mills, Ann Laura Stoler, and others have discussed the shifting positions of European and North American women in colonial spaces as both colonizing agents and colonized subjects, as producers of imperial knowledge, and as margin dwellers. While the literature on women's travel writing suggests that there is something distinct about this writing, it can be difficult to Mills writes that the primary distinction between the travel writing of men and that created by women is not so much one of content, but of reception; 'the way that women's writing is judged and processed'.[9] Pratt argues that women's travel narratives, while espousing imperialist agendas, often situate themselves within domestic spaces. She explains, 'If the men's job was to collect and possess everything else, these women travelers sought first and foremost to collect and possess themselves. Their territorial claim was to private space, a personal, room-sized empire'.[10] While Mills asserts that the essentialist category of 'women travel writers' can be problematic, she does go on to argue that:

women travel writers were unable to adopt the imperialist voice with the ease with which male writers did. . .. Because of their oppressive socialisation and marginal position in relation to imperialism, despite their generally privileged class position, women writers tended to concentrate on descriptions of people as individuals, rather than on statements about the race as a whole. [11]

As I will discuss, Grimshaw had complex relationships to racial and class difference that are not so easy to categorize and often wrote from a colonialist perspective. Similarly, Pratt's notion that women's travel writing lies primarily within the realm of the domestic does not necessarily apply to Stevenson or Grimshaw. It is possible to expand a definition of the domestic to include not merely an architectural-social space, but a discursive site, containing a range of social, sexual, 
and political bodies, yet both Stevenson and Grimshaw remain difficult to contain within a limited spatial relationship to their travel sites. Certainly their gender allowed them access to some semiprivate Island women's worlds, as the discussion of textile production (the domain of women in Polynesia) by both authors would attest. Yet their narratives are primarily located within the broader public area of Western and Pacific contact: the beach, the ship's deck, and the common areas of the village. Further, their relationship to differences of class and race was informed by their colonial relationship to the islands they visited.

Although my reading of Stevenson and Grimshaw points out some of the limitations of these early studies of women and travel, I nevertheless see the writings of Mills and Pratt as foundational texts in a conversation that has emerged in recent years around the relationship between gender and empire. Ann Stoler's work will be discussed more extensively below in relationship to Beatrice Grimshaw's writings; however, I introduce her here as another key figure in this discourse. Stoler argues that the very meaning of being 'European' transformed in the colonial sphere: in this space was produced not a self-and-other binary of colonizer and colonized, but rather a complex web of race and class relations that existed outside of the more structured hierarchy intended to be upheld through the regulations of the colonial metropole. As the state of being 'European' was potentially ambivalent and determined through arbitrary categories such as skin color and citizenship, constructing 'Europeanness'-and therefore positions of dominance-required, as Stoler argues, 'regulating the sexual, conjugal, and domestic life of both European colonials and their subjects,. 12 In Stoler's case studies in the Netherlands Indies at the turn of the twentieth century-and one could argue more broadly in the European colonized world-the presence of European women as colonial wives complicated relationships between colonizer and colonized in their role as a substitute for earlier forms of sexual relationships between European men and Indigenous women. Indeed, for Stoler the politics of colonialism were played out in private spheres, especially through concubinage, the production of mixed-race children, relationships (sexual and otherwise) with household servants and wet nurses, and the politics of repatriation, in ways that suggest the 'domestic' spaces were perhaps the most racially and sexually conflated of the empire, the most subject to both imperial regulation and surveillance and, at the same time, to subversion of these imposed orders-and therefore the most appropriate metonyms for the lived experience of empire. Stoler's work suggests-and my analysis of Grimshaw and Stevenson furthers this suggestion-that relationships between self and other, colonizer and colonized, did not always fall along a clearcut binary.

When placed in conversation with dialogues in post-colonial theory, such as Stoler's, the work of Mills, Pratt, and others enables a more critical consideration of Grimshaw and Stevenson. While Pratt's assertion that colonizing women asserted their control over the domestic domain seems, at first consideration, to suggest a limited and universal experience, Stoler's work draws on this concept to consider the ways intimate spaces take on metaphorical relationships to the broader colonial world. More recent discussions of women's travel writing have also engaged with these earlier studies. Cheryl McEwan's analysis of women's travel writing from West Africa draws on Mills's notion that women travel writers are at once marginal actors on the colonial stage and complicit in the dominant schemes of imperialism. She writes, 'Freed from the "complicity/resistance" dialectic, one can begin to explore ways of producing critical feminist 
readings of the texts of British women travellers', and goes on to argue that an engagement with post-colonial theory, particularly feminist post-colonial theory, adds nuance to an analysis that otherwise risks universalizing the experiences of both the European women and their colonized subjects. 13 In the following sections, I address the complex and often messy interworkings of self and other, public and private, that are created through Stevenson's and Grimshaw's writings. Rather than producing an incommensurable field of conflicting representations, the intersections and contradictions in their texts reveal the complicated texture of empire, of European women's place in this empire, and of the discrepant realizations of white women's experiences in the colonized Pacific at the turn of the twentieth century.

\section{FEARSOME PLEASURES: THE ENCOUNTERS OF BEATRICE GRIMSHAW}

Grimshaw was born in Lancashire in 1870 but raised primarily in Ireland. Her journey to the Pacific Islands was a direct result of her career as a freelance journalist and tour promoter. While traveling she contributed to the London-based Daily Graphic and published both novels and narrative prose based on her Island journeys. After traveling through the Pacific, she settled in what was then British Papua (now Papua New Guinea) for twenty-seven years before retiring to Australia in 1936. By 1908 her national identity and loyalty had shifted once again when she was commissioned by the Australian Prime Minister to write pamphlets encouraging settlement and investment in newly-acquired Papua.[14] Grimshaw was connected, at various times, with the Lieutenant Governor of Papua, Sir Hubert Murray, and the Government Tax Collector, William Little, but whatever her relationships with these men might have been, she remained unmarried. Her numerous romance novels and travel writings have passed into obscurity, her books are out of print, and my own research has revealed scant critical analysis of her work. [15] Certainly there is much in her writing to render Grimshaw distasteful and unsettling to contemporary audiences. In spite of her own, unconventional, independence, Grimshaw's writings were socially and politically very conservative. In both her fiction and her journalistic writing, she offered detailed advice on appropriate female domestic behavior as well as suggestions for prosperous colonial settlin $\mathrm{g}$. Racism is a determining marker of Grimshaw's writing as well, particularly in her works set in Melanesia, underscoring Grimshaw's strong Australian alliance in her later life and Australian colonial interests in the area.[16] Nevertheless, in the prime of her career she was very well known to popular audiences. As late as the 1930s she was a best-selling author, and several of her books were made into tllms.[17] In the Strange South Seas is both conventional and unexpected.

The British colonial presence in the Pacific at the turn of the twentieth century is distinctly evident throughout the text. While Britain's colonial investment in the area was perhaps (arguably) less orchestrated than its larger and more profitable projects in North Africa and India, Britain's colonial influence was nevertheless widespread and clearly present in the Islands. Fiji, Tonga, the Cook Islands, and other groups came under some form of British rule during this period. Even where Britain did not maintain direct political control over certain islands, the commonwealth nations of Australia and New Zealand were key political powers in the area, and British influence continued through missionization and the presence of British 
'planters and merchants' .[18] Indeed, although mission presence remained, the late nineteenthcentury British colonial project, both direct and indirect, focused on the deVelopment of the plantation and trade economy, especially copra and sugar production. [19] The political power obtained through the accumulation of capital and land furthered the British (or British-aftlliated) economic and social stronghold on the Pacific.[20] Grimshaw's relationship to these colonial endeavors manifests as her keen interest and investment in economic production, and the maintenance of social hierarchies this production requires.[21] For Grimshaw, the social landscape of the Pacific was based on multilevel, hierarchical rankings of Westerners as well as Islanders, yet she continually notes that it was the white population that was particularly threatened by degeneracy. As Stoler has noted, the fear of 'potential and actual' poor whites, particularly nonproductive men, led to a number of regulations on marriage and community.[22] If the colonial subject was meant to be a moral and economic model for the colonized, the presence of unseemly behavior, variously defined, was a direct threat to the hegemony of imperial power. Indeed, as Stoler adds, it was European women who were 'positioned as the bearers of a redefined colonial morality'; through proper social behavior and the keeping of an appropriately structured and hierarchical household, the European woman was at once in need of protection from the implied sexual threat of colonized men and degenerate white men, while also responsible for producing models of acceptable behavior.[23]

Certain photographs in the text speak to Grimshaw's desire to maintain a colonial class hierarchy and proper gender roles. Her photographs of single Indigenous women demonstrate Grimshaw's firm connection with typical exoticist representations: rather than demonstrating the possibilities for colonial productivity, these images suggest the potential for languid pleasure in the tropics. Tahitian Native and Tahitian Beauty, which appear next to one another in the text (Figure 1), are one example.[24] The women's breasts are covered by pareus worn tied around their upper bodies, yet their long, loose hair cascades around their bare shoulders. The model in Tahitian Native is adorned with flowers and shell jewelry, and averts her gaze. In Tahitian Beauty, the woman looks directly at the viewer, although her face is shadowed by a large hat; she is situated within a natural landscape of dense foliage. In these examples the framing and pose of her images suggest the eroto-ethnographic style of Alfred Burton and other popular photographers in the Pacific views trade. In contrast, group shots of Islanders pose the subjects in aligned rows, recalling missionary images meant to communicate the Droductivitv of EuroAmerican Dresence. 


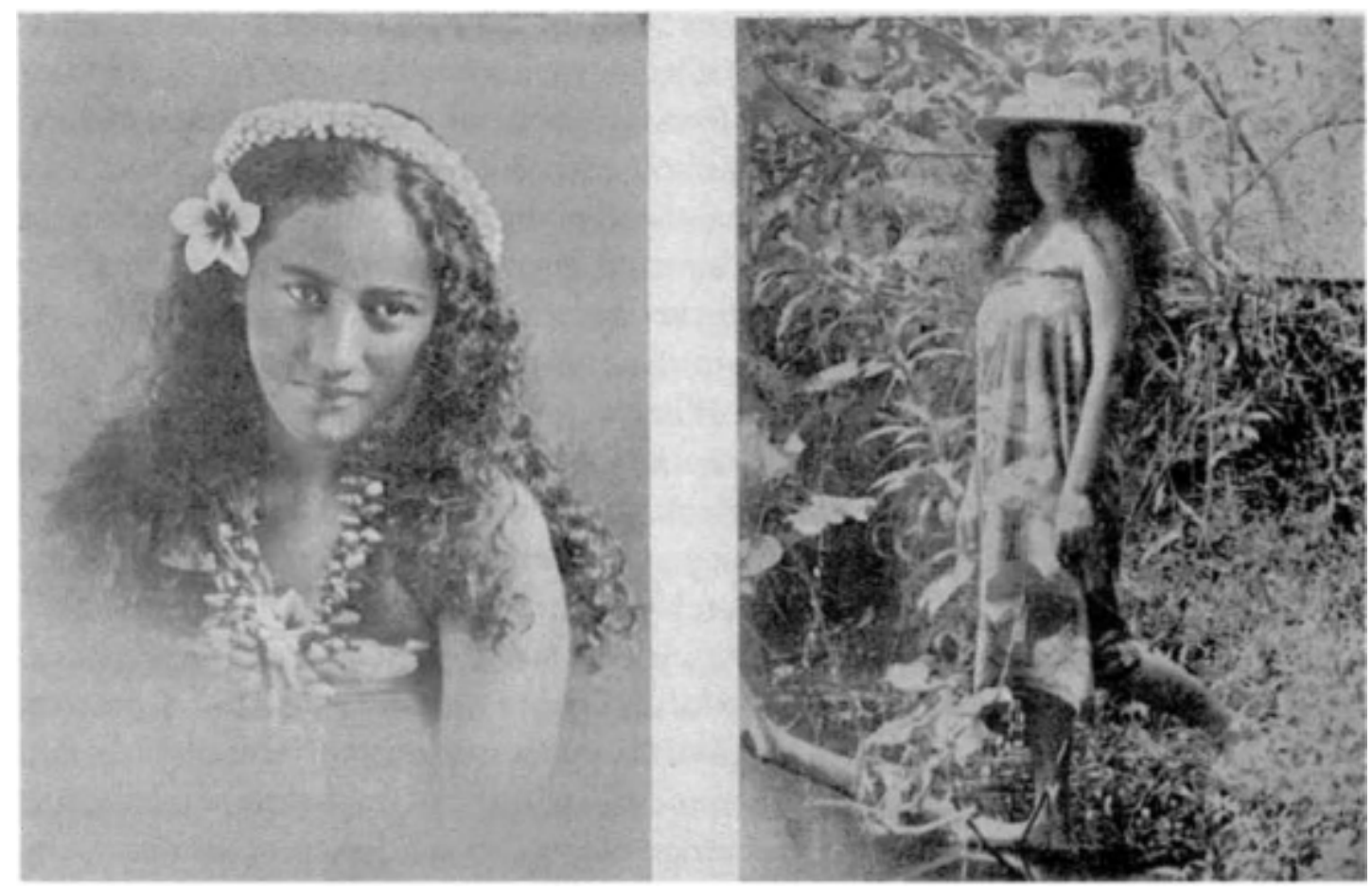

Figure 1 Beatrice Grimshaw (?), Tahitian Native and Tahitian Beauty, photograph, c.1904. Source: Grimshaw 1905.

In Women of Rarotonga, Mat-Making (Figure 2), an activity that normally would involve several women sitting in a circle working on their own mats is represented as a number of women and several small children standing in rows behind a large mat. Four adult men also occupy the back row of the photograph and are visually included in a women's domain, but textually erased by the caption. Their masculine presence also is made safe through their association with domesticity and by their physical separation from Grimshaw. Both the women and the men are dressed in European clothing that entirely covers their bodies. The women and the mat, itself a domestic object, mediate between the men's bodies and Grimshaw's. In the photograph, the gendered divisions of domestic space are articulated through Grimshaw's own visual language, which required regulation and ordering of the body through the context of productive labor. 


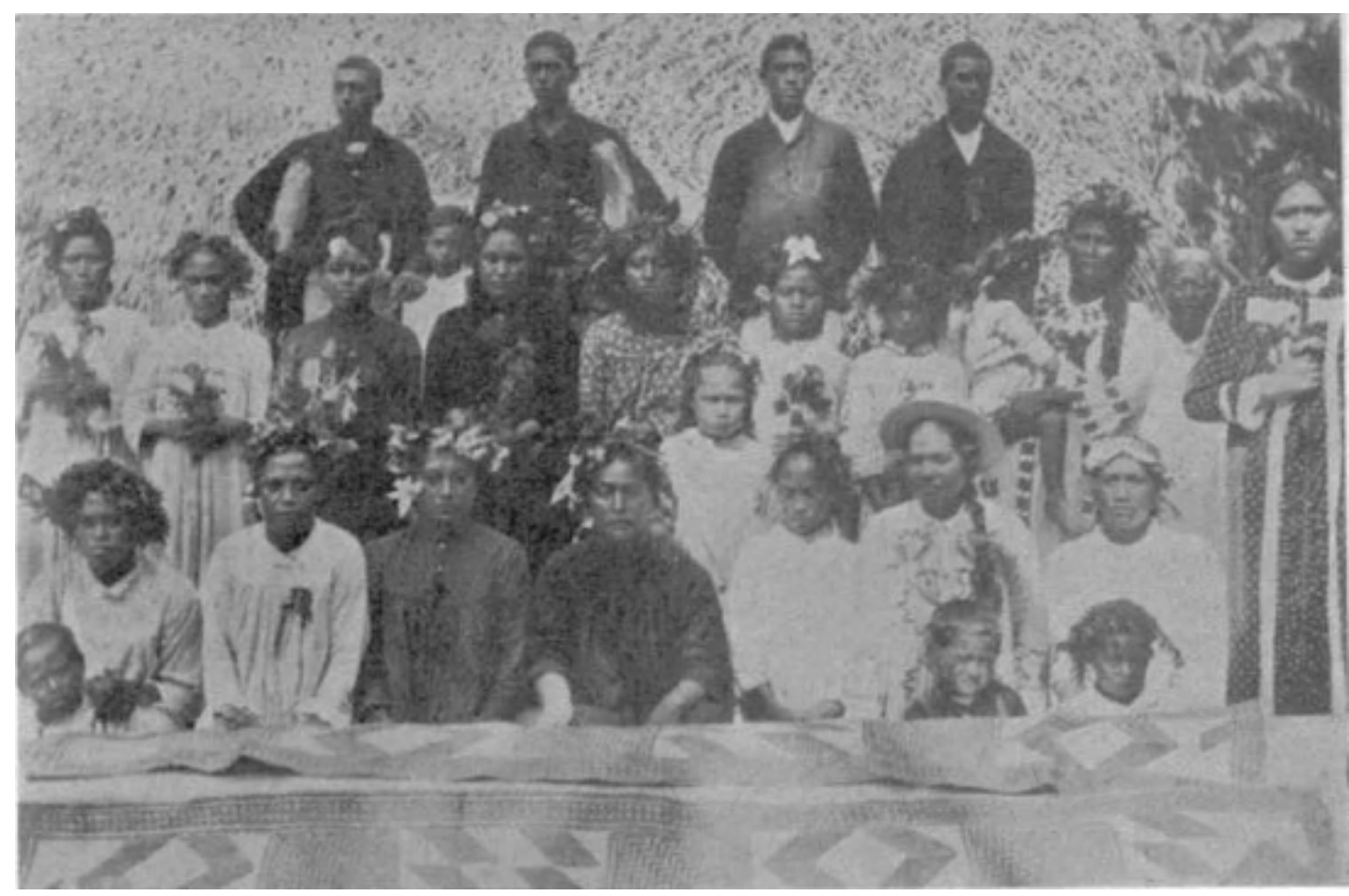

Figure 2 Beatrice Grimshaw (?), Women ofRarotonga, Mat-Making, photograph, c.1904. Source: Grimshaw 1905.

Grimshaw's representations of Pacific men are particularly devoted to illustrating the benefits of native labor. In her photograph captioned Cutting Copra (Figure 3), native labor and its benefits to a settler-colonial trade economy are aestheticized. In the center of the photograph, a man fills a sack larger than his own seated body with copra; the top register of the photograph is given visual weight with a vertical, solid coconut palm forest punctuated by a grazing horse. The image accompanies a long passage discussing the cultivation and export possibilities of coconuts, vanilla, bananas, limes, and chili peppers. The additional threat of sexual aggression by the active male and the sexual tension of this threat is erased in the caption of the photograph, which reduces the image to one of imperial productivity. Further, the man is alone, isolated from his collective Indigenous community. Grimshaw's central investment in the economic potential of the various island groups also serves to neutralize her fear of the unproductive male by representing his body in the service of the colonial economy. 


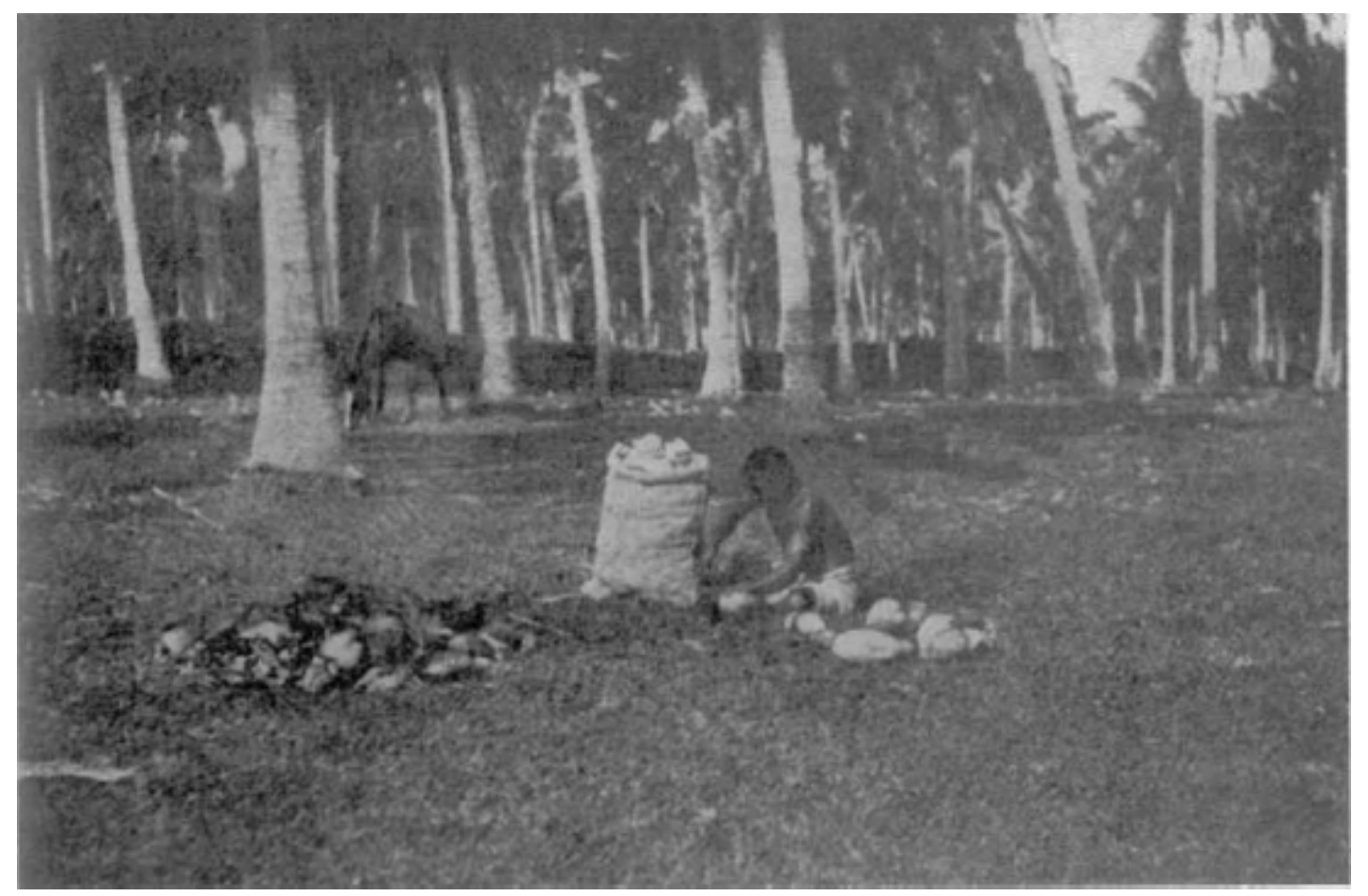

Figure 3 Beatrice Grimshaw (?), Cutting Copra, photograph, c.1904. Source: Grimshaw 1905.

The white settlers who fall from grace-thus subverting the colonial hierarchy-are, for Grimshaw, the most deviant of colonial actors, failing to actively participate in the productive imperial economy. In white men, this translates as laziness, as a refusal to work; for white women, it manifests as a refusal of domestic productivity, of keeping an appropriate house with an appropriate spouse and producing appropriate children. Grimshaw distances herself from the unfixed population of the beachcomber, the 'remittance man', and the 'ne'er-do-well', writing:

Honesty, sobriety, and industry repay their possessor as almost nowhere in the world. Yet, with all this, the white settler in the Pacific Islands is generally of a more or less undesirable kind . ... There are men who have 'gone native' in most of the Pacific groups, living in the palm-leaf huts with the villagers-but a white man in a waistcloth and a bush of long hair, sleeping on a mat and living on wild fruit and scraps given by the generous natives, drunk half the time and infinitely lower, in his soberest hours, than the colored folk who unwisely put up with him, is not a happy spectacle.[25]

The dangers for European women in the tropics are also noted in the text. Grimshaw relates the tale of a young British widow who marries a Pacific Island man. Prior to this marriage, the woman is described as 'young and handsome, [with] many friends of her own'; her first husband is 'a schooner captain, a man of good family and connections, who liked the wild roving life of the Pacific, yet managed to retain a number of acquaintances of his own class in Auckland and Tahiti'. After his death, she marries a native man, 'good-looking and attractive, but threequarters savage'. She bears the man several children and is then deserted by him. Refused re- 
acceptance into white society, the woman 'who sinned against her race and found no forgiveness' dies in solitude and despair.[26]

Nevertheless, within the limited structures of the colonial sphere there existed the potential for bourgeois leisure, suggested by the experience of languidness. It is in the opposition between the lazy and the languid that Grimshaw defends her pleasurable experience as a solitary traveler against the threatening existence of the lazy settler. Languidness is a product of bourgeois leisure; laziness is a rejection of the Protestant work ethic. The lazy settler, particularly the unattached white men Grimshaw critiques in the passage above, is the site of the greatest failure of colonialism's organizing principles. Within the rigors of the colonial scheme, however, lies the possibility for a certain degree ofleisure in the bourgeois traveler, a side benefit of situating oneself at the top of the colonial hierarchy. Languidness is central to Grimshaw's construction of her own experience as a European traveler in the tropics. In the Strange South Seas is permeated with a sensual slowness. Her descriptions of Tahiti Nui's landscape focus on heavy scents, lush foliage, and 'sweet laziness';27 the island is a 'pearly light of a sunrise pure as a down of earliest Eden'.28 Still, in a colonialist climate pervaded by the implied sexual threat of men of color to white women, the woman characterized as strong or virtuous resists total slippage.

Grimshaw's self-representations are perhaps the most complex in the text; in these, the tension between the appropriately languid and the dangerously lazy plays out in especially telling ways. Clothing-worn or taken off, European and native-is a central metaphor for this tension. As Margaret Jolly stresses, 'She constantly reminds us of her own female body in exotic places, in her muslin nightdress, under the mosquito net, undoing her plaits,..[29] While Grimshaw's everyday garments contain and protect her body and prevent excessive movement, when she wears a Tahitian missionary-style dress, she experiences new sensations through her body. Grimshaw describes being dressed in native clothing by her Tahitian hostess/innkeeper:

before we reach the market she proceeds to dress me up Tahitian fashion, with long necklaces of sweet white blossoms round my neck, falling all over my dress, and a heavy crown of closely woven gardenias on my head, instead of my hat, which she removes, and politely carries. She wants to pull my hair down as well, but in a temperature of eighty degrees the idea does not sound so tempting, so I decline to follow Tahitian custom further. Besides, there is really no knowing where she would stop![30]

Although the Mother Hubbard dress would have covered the same parts of the body as Grimshaw's usual clothing, being long-sleeved and ankle-length, the missionary gown would have been waistless and made oflight cotton cloth. I imagine Grimshaw experiencing the sensation of her body loosening beneath the lightweight cloth, feeling her sweat evaporate as the cool island early-morning breezes course through and beneath the dress, surrounded by the heavy and intoxicating sweetness of tiare blossoms. Perhaps this is the least covered she has even been in a public place, heightened by the forbidden thrill of feeling as though she were wearing her nightclothes in public-she refers to the dresses as 'nightgowns' -with all the per formative and transgressive excitement that would imply. She acknowledges the ease with 
which one could slip over the edge, discussing her feelings of tiredness and languidness brought on by food, heat, and scent. However, while her body expands beneath her loose gown, her hair remains solidly pinned in its motionless, elaborate, tightly-wound coif.

Grimshaw indeed goes to great lengths to assert that she retains her place of moral and social privilege in spite of many tempting opportunities to do otherwise. She often constructs herself as an object of the gaze, inviting the look and touch of the Islanders and inverting the binary of colonial spectator/Other spectacle. On the island of Atiu, in the Cook Islands, Grimshaw writes that she became a local amusement, an object to be touched, a spectacle to be examined:

I do not think any white woman had been up to the settlement before I visited it, and the curiosity of the girls was uncontrollable .... they slyly felt my hair to see if the coils were attached to my head in Nature's own way, ... ther rubbed my dress material in their fingers, they poked me all over to see if I was real.[31]

In another self-representation, Grimshaw sees herself from a leper's point of view:

there she was, with two arms, and two legs, and a head, and a funny gown fastened in about the middle, and the most remarkable yellow shoes, and a ring, and a watch, which showed her to be extraordinarily wealthy, and a pale smooth face, not at all like a man's, and hair that was brown, not black-how odd![32]

By stating that the Islanders she encountered looked at her, Grimshaw reduces the potential of any desire, sexual or otherwise, in her own gaze by making herself the subject rather than the agent of the gaze. As Ruth Jenkins has argued, the spectator/ spectacle relationship is especially complicated in the situation of single women travelers. Jenkins writes, 'Many women were faced with the twin desires to remain "appropriate" and still enact their "inappropriate" desires. Many felt compelled to masquerade their intentions or deflect criticism by maintaining a rigorous code of propriety,[33] Particularly through their encounters with Other women, Jenkins explains that Victorian women travelers are placed in complex and potentially inappropriate situations, in which their behavior-unchaperoned movement, refusal of a domestic role, looking at other women-must be assuaged for their reading public. Adventure is acceptable, and indeed demanded by readers; transgression and abjection are not. Jenkins argues, intriguingly, that the primary contact produced in these situations is not between self and other, but an 'internalized contact zone' in which the 'authentic' (potentially inappropriate) self encounters the one 'constructed within the context of cultural expectation'. [34] When Grimshaw directs the gaze of her subjects back at herself, she reasserts her dominant position as a colonizer and a morally and socially appropriate woman by neutralizing any perceptions of misbehavior on her part and asserting that, in spite of her unconventional status as a single woman traveler, she nevertheless maintains appropriate boundaries of propriety and social hierarchy.

Grimshaw's hypervisibility is ultimately the hypervisibility of her whiteness: as a woman she is not particularly notable, but as a white woman traveling by herself she steps outside the expectations of turn-of-the-century womanhood and is an oddity to other Europeans and, according to her text, to the Islanders she encounters. Grimshaw's unusual position as a solitary traveler, and the freedoms she thus enjoyed, are not derived from a radical questioning of 
contemporary racial or gender hierarchies; indeed, her writing often re-inscribes a bourgeois norm and stresses the positive, civilizing presence of colonial actors. Yet her work also challenges, on a very basic level, the idea of a 'male' gaze, which assumes a male artist producing for a male viewer, neither of which is the case for Grimshaw's work. More significantly, the conventions of Grimshaw's text invite the reconsideration of the 'gaze' as either male or female; instead, her work is more effectively considered as a product of a European colonial 'gaze' produced through the intersection of race, class, gender, and national identity. As Indira Ghose has argued, analyses of women's travel writing must move away from the myth of a universal, unified subject identified only by gender. She explains, 'The interesting thing about the female gaze is the way it is refracted by other, controlling gazes .... What needs to be scrutinized is the site from which women gaze, that is the positions of power in which they are located'. [35] The unproblematized notion of the 'gaze' erases distinctions of class, race, and colonial hegemony, all of which inform Grimshaw's work in important ways. Further, by taking on a position of class and race privilege, and therefore distancing herself from her subjects, Grimshaw places herself firmly within the center of the Pacific colonial world, a direct agent of the British colonial-industrial project. The conventional rather than radical nature marks her as a significant actor in Western representations of the Pacific Islands precisely because these conventions require us to interrogate the intersection of gazes that play out in these representations, rather than considering them solely from the basis of gender.

\section{FANNY STEVENSON: SOCIAL BODIES AND THE PLEASURE OF DESCRIBING}

Stevenson was born in 1840 to an Indiana farming family. Her nearly constant movement took her around a number of geographical points and historical moments: the frontier of Gold Rush Nevada, and the resulting prosperity of San Francisco, Oakland, and Monterey; Paris and the French countryside of the Impressionists; and Samoa during a period of chiefly conflicts.[36] In the narrative of her 1890 journey on the Janet Nichol, there is a tough resourcefulness and wry humor to her writing that exists alongside, and in tension with, a sense of wonder and delight with her surroundings: 'I have mended the bellows of our camera, where it has been eaten by cockroaches, with sticking-plaster,.[37] As the independent and robust American 'lady traveler' accompanied by her famous but physically weak Scottish husband, Robert Louis Stevenson, Fanny Stevenson herself occupied a shifting social position. A close reading of Stevenson's texts, and particularly an analysis of the juxtaposition of photographs with her written text, reveals some of the author's own intentions through her representation of specific moments of her journey.[38]

Stevenson certainly takes pleasure in describing, in the telling of a story, yet her writings indicate both enchantment with Island life and an understanding of the sometimes harsh realities of that life. Her own interactions with cultural and linguistic difference in Gold Rush Nevada, Spanish California, and the French countryside gave her a number of tools to interpret the events going on around her and to translate them into an unfolding narrative and a series of images. Her narrative is written against a background of labor: the travelers encounter blackbirders, islands decimated by the slave trade, whalers, traders, and exhausted mission 
wives. Indeed, Roslyn Jolly notes that Stevenson's writing reveals acute distinctions in the nature of intercultural encounter in the islands most decimated by the slave trade and other colonial laboring practices.[39] Settler women's labor in particular was of interest to Stevenson. After a brief visit to a mission family on the island of 'Nuieue' (Niue), during which the entire ship was feasted, Stevenson wrote, 'It was an excellent meal, which I should have thoroughly enjoyed had I not felt like a cannibal and that I was eating Mrs. Lawes. But this it is to be a missionary wife'.[40] In another passage she remarks candidly on the death from homesickness of an indentured laborer: 'both Arriki and a friend of his began to droop and became sullen, and then went quite mad; soon after they died at about the same time from no apparent disease, but ... "just plain homesickness"'.[41]The trope of the 'lazy native' typical of colonial texts, including Grimshaw's, becomes, in Stevenson's narrative, a marker of death, an interruption in her otherwise pleasant and pleasurable narrative. The passage is also remarkable for what it reveals about the colonial situation at the end of the nineteenth century: the development of plantation economies and the continual conscription of Indigenous labor had multiple manifestations for Indigenous communities as well as colonial ones, particularly through displacement, deterritorialization, and the attempt to undermine Indigenous community structures. While brief, Stevenson's passage gives a glimpse of the less-than-paradisiacal situation of many Indigenous actors within a space otherwise presented as providing boundless opportunity for the diligent settler in a number of colonial accounts.

The images placed within the text both coincide with her written narrative and interrupt it. Bodies are not always entirely contained within a photograph, and the cropped figures at the edges of the frame give a panoramic sense of being entirely surrounded by other people, of dwelling in a place where bodies freely come into contact with one another. The photograph captioned Natives Dancing recalls the typical arrival scene, with celiain unusual elements (Figure 4). The photograph accompanies a long description of the Steven sons' visit to Manihiki in the northern Cook Islands. As with many arrival scenes in the Pacific, Stevenson describes being greeted by a group of dancers:

On the way we passed a crowd of dancers, ranged in two rows, the women on one side, the men, on the other, in front of the 'speak-house' .... The European costumes in which most of the people had dressed for our reception rather spoiled the effect, though many wore wreaths and headdresses made of dyed leaves.[42] 


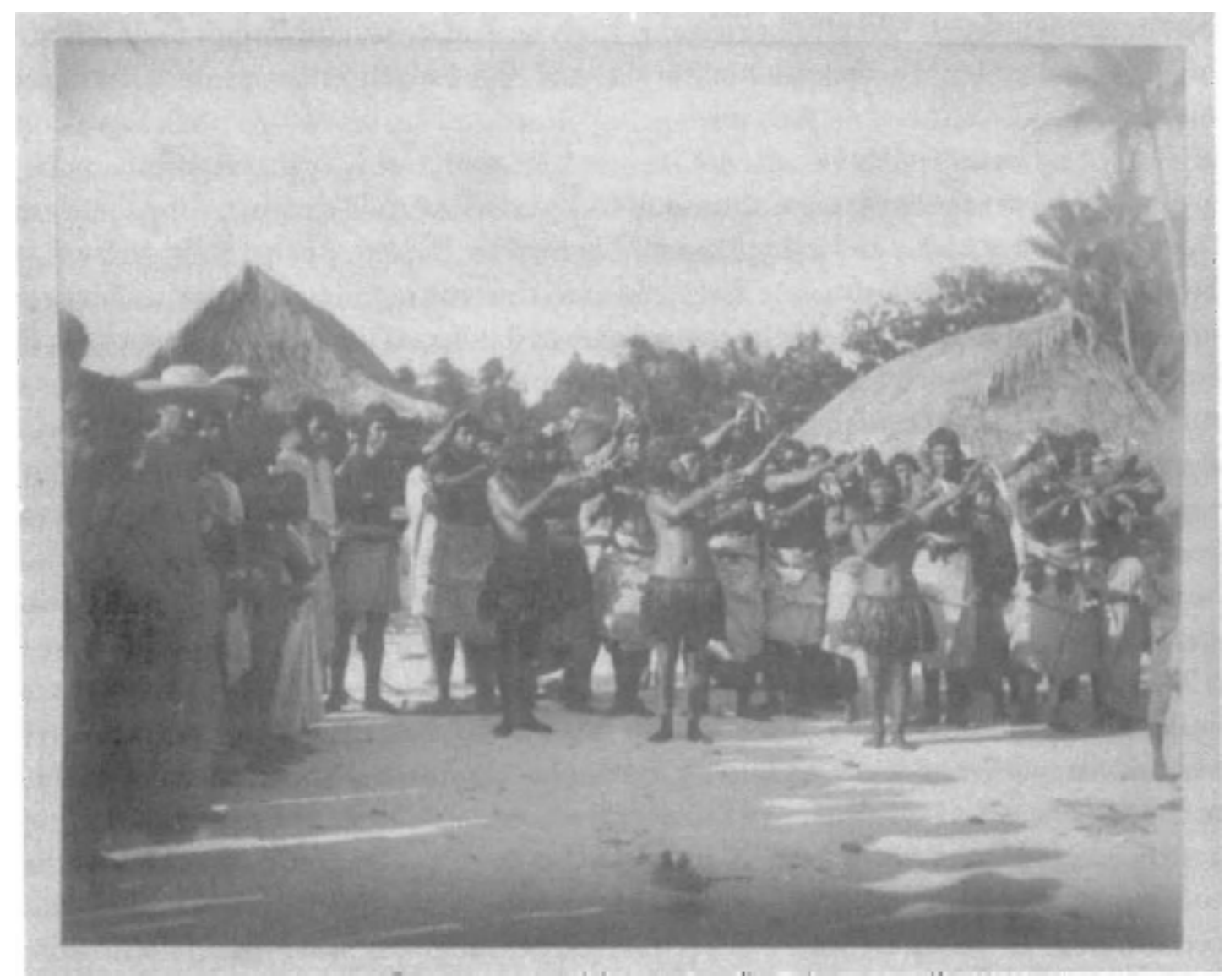

Figure 4 Photographer unknown (Lloyd Osbourne?) (from The Cruise of the 'Janet Nichol'), Natives Dancing, photograph, c.1890. Source: Stevenson 1914. Reprinted with kind permission of the Writer's Museum and City of Edinburgh Council.

A photograph several pages later illustrates this moment. The Islanders in the photograph, both dancers and their audience, literally surround the viewer, disappearing into the edge of the frame. On the left side of the picture, the crowding of people and the short depth of field results in bodies literally fading into darkness. A number of the dancers and audience gaze into the camera, including a child on the right edge of the photograph, who in bending over succeeds in including rather than cropping himself from the frame. Although Stevenson in her text describes the subjects as being 'ranged in two rows', the bodies in the image are crowded together, forming a casual semicircle around both photographer and viewer. Unlike more typical colonialmissionary images, whose subjects are often dressed in Western clothing and standing in front of a Western architectural structure, the Islanders in this image wear an assortment of Indigenous and Western clothing, and pose casually in front of a background of traditional thatched architectural buildings.[43] This intimacy, the surrounding of the traveling subject with Indigenous bodies rather than the arrangement of bodies in rows, sets the illustrations in Stevenson's text apart from more typical representations of similar scenes. 
Another photograph from the same section of the book reveals that the cultural dynamics of the Pacific theater were drawn along the lines of race and rank (Figure 5). In the photograph, the 'King of Manihiki', wearing a velvet poncho with a star brooch, a moustache and white trousers, poses with the 'Island Judge' in a white jacket and colored pareu, a 'kanaka-ised' beachcomber clad in a woven poncho, and Tin Jack, a trader traveling on the Janet Nichol with the Stevensons.[44] An unidentified woman sits between the 'judge' and the 'king', and a Manihikian man and boy sit on the porch of a nearby building. In this photograph, the complexities of the social milieu of the nineteenth-century Pacific are made visually evident. The Islanders wear a mixture of local and Western-style cotton clothing: loose cotton shirts, trousers or a pareu, and woven hats. Through clothing and body posture, both the Westerners and the Islanders in the image negotiate cultural contact and, for the Islanders, their situation as colonized subjects. The royal insignia of the 'king' was not unusual, as Western emblems of rank were acquired through trade and adopted by Islanders in their own system of hierarchical designation.

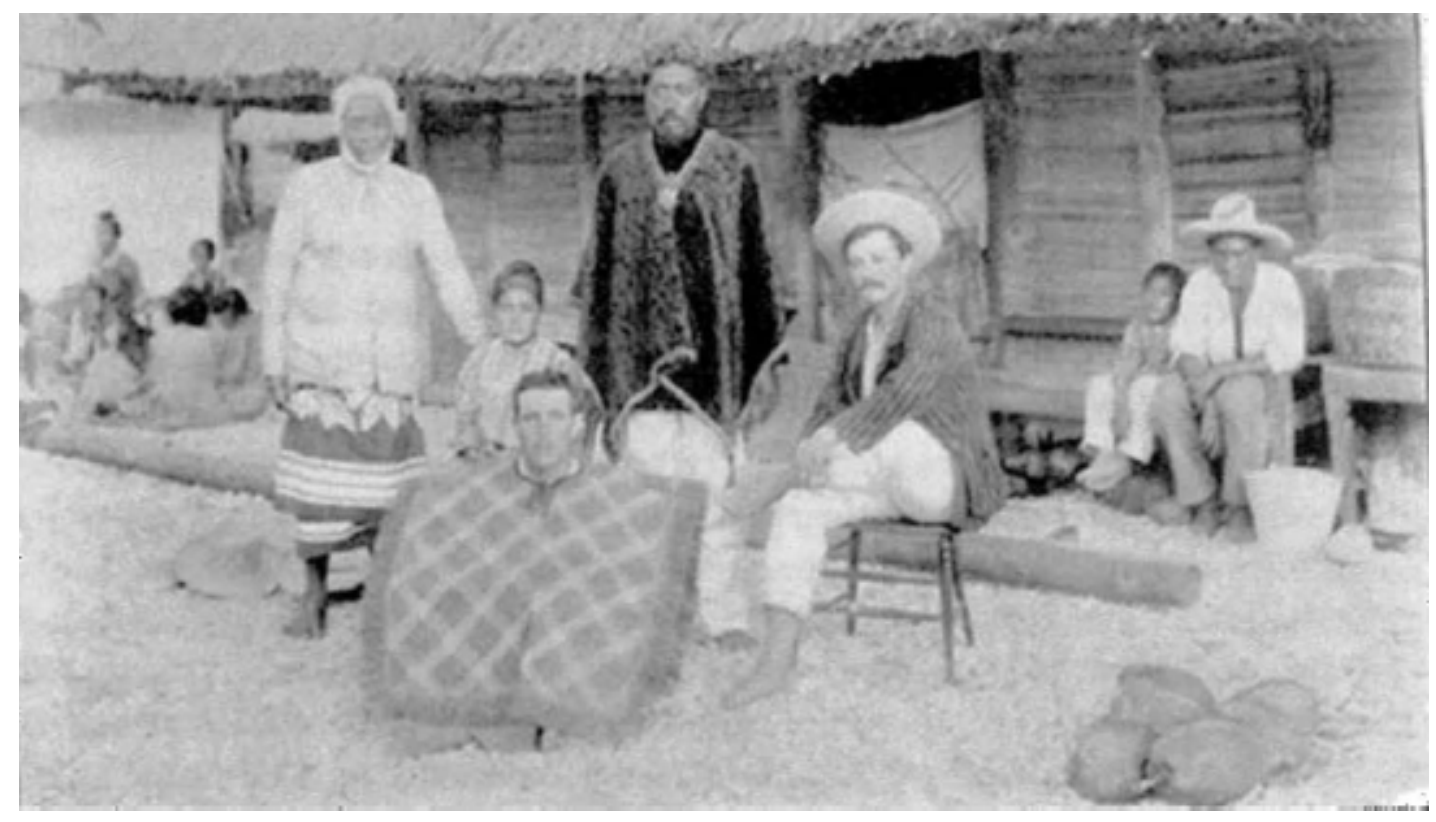

Figure 5 Photographer unknown (Lloyd Osbourne?) (from The Cruise of the 'Janet Nichol'), The King of Manihiki in the centre, with the Island Judge on his right and Tin Jack, seated, on his left. The man squatting in the foreground is one of the beach-combers, photograph, c.1890. Source: Stevenson 1914. Reprinted with kind permission of the Writer's Museum and City of Edinburgh Council.

The tiputa-style poncho worn by the beachcomber recalls woven and tapa ponchos worn by Island men earlier in the century, but by the late nineteenth century this style had been abandoned in favor of cotton shirts. Visually, the poncho weirdly erases the man's body, and its rough weave and heavy fringe more closely resemble a floor mat than fine mats worn for auspicious occasions. While Stevenson remarks on the curious combination of garments and adornments worn by the Islanders, it is the beachcomber- himself a floating figure in the social world of the Pacific, dependent upon the locals for food, attached to nowhere-and his floor-matclad body who is the truly weird element of the photograph, the element of not-belonging. Out of 
place, unrooted, the beachcomber occupies a cultural and geographical gap that is not addressed in the text but is given visual punctuation through the photograph accompanying this passage. Further, through the distinction of the chiefly Islanders from working-class Europeans, Indigenous class order is maintained outside of Euro-American racial hierarchies.

The photographs in The Cruise of the 'Janet Nichol' also contribute to the construction of intimate relationships between Stevenson and specific, named subjects. A photograph of Fanny and Robert Louis Stevenson with their friends Nan Tok and Natakanti on Butaritari Island (Kiribati) points to the intimacies of their relationships with Islanders (Figure 6). In a footnote Stevenson describes leaving their lodgings to explore the island. It was a dangerous time as, she relates, 'The King had raised the tapu from drink, consequently, the entire island, including his dull majesty, was wildly drunk on 'sour toddy,' .... which is the most dangerous intoxicant in the world, as it incites its users in a frenzied desire to shed blood'.[45] During her walk Stevenson encounters the two Islanders who, alarmed, escort her back to her lodgings. Misunderstanding their desire to lead her to safety as an attempt at capture, the author describes her first encounter with her 'captors' as follows: 'they were not reassuring companions, judging from their outer appearances, as they were unkempt, clad in nothing but a small fragment, each, of dirty, old gunny sack, and their faces were haggard and anxious,..[46] Later, recognizing their fears for her safety, Stevenson and her husband become friends with the Island couple. The initial misunderstanding of their encounter with the Island couple is transformed into a relationship given heightened intimacy by the photograph accompanying the narrative description of the event. 


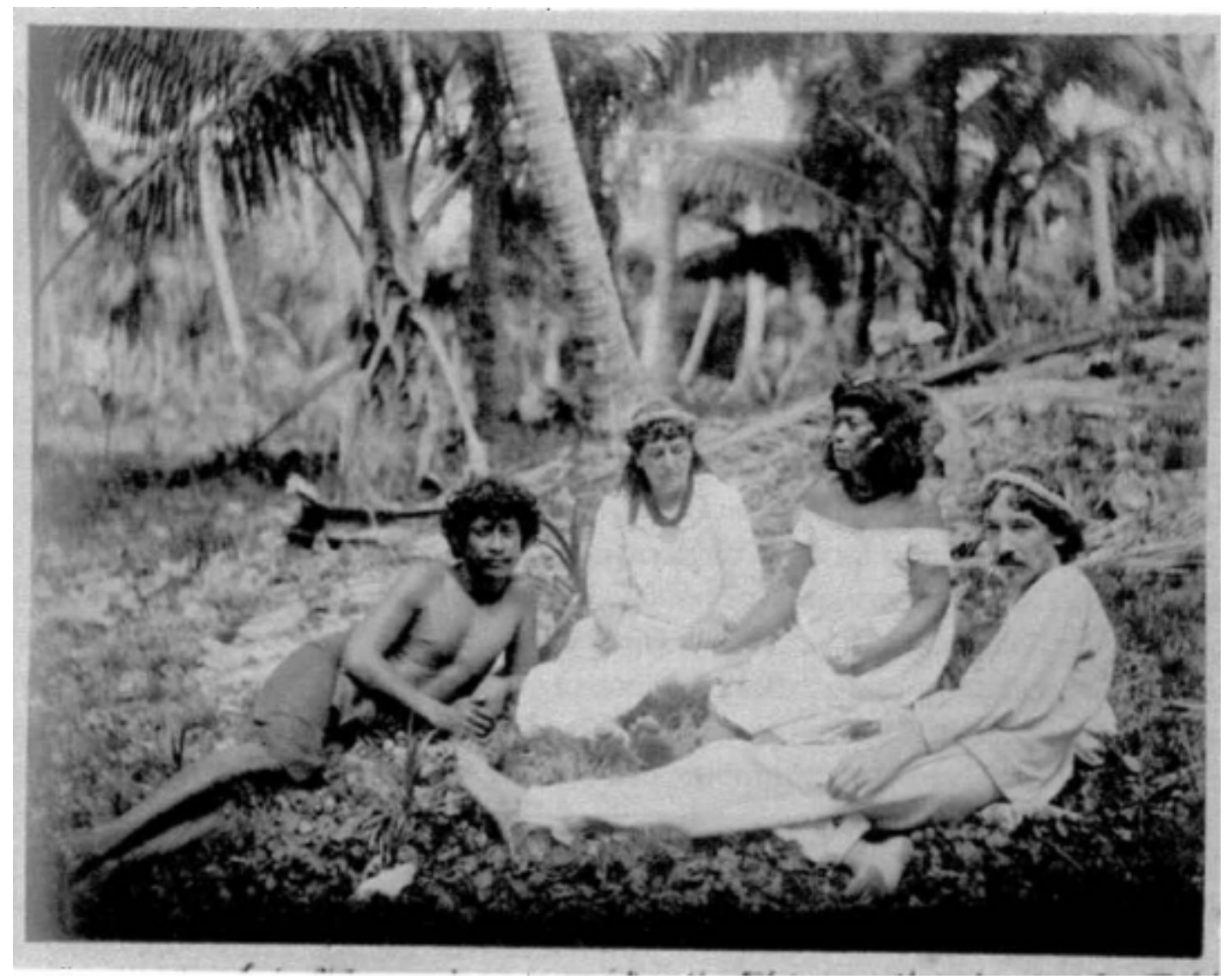

Figure 6 Photographer unknown (Lloyd Osbourne?) (from The Cruise of the 'Janet Nichol'), Mr. and Mrs. Stevenson in company with Nan Tok and Natakanti on Butaritari Island, photograph, c.1890. Source: Stevenson 1914. Reprinted with kind permission of the Writer's Museum and City of Edinburgh Council.

In the photograph, a sitting Fanny Stevenson and Natakanti are flanked by reclining Nan Tok and Robert Louis Stevenson in a natural, non-studio setting, surrounded by palms, banana trees, and tangles of vines. The two women are barefoot, wearing their hair loose, adorned with similar multistranded necklaces of seeds or small shells, and clad in similar white dresses with piping or embroidery down the front, although Natakanti's is short-sleeved and worn off the shoulder. Fanny Stevenson, occupying the center of the photograph, looks down at her hand entwined with Natakanti's, and holds a cigarette in the other hand. Sitting between Fanny and Robert Louis Stevenson, Natakanti, gazing into the distance, visually anchors the vertical and horizontal planes of the photograph. Robert Louis Stevenson is wearing loose white trousers and a blousy white shirt, with a hair band of white seeds or shells. Fanny's feet are not visible, but like Nan Tok and Natakanti, Robert Louis Stevenson is barefoot, and the soles of his feet are dirty. Only Nan Tok looks directly at the camera, and is wearing darkcolored pantaloons. The Islanders' transformation from gunny-sack-wearing threat to intimate friends is sublimely articulated through the photograph. The dynamic of gazes within the photograph and the physical entanglement, relaxation and comfort of the two couples recall popular images of the bourgeois countryside outing, such as Edouard Manet's Dejeuner sur l'Herbe of 1862. The 
Stevensons present themselves as the friendly outside presence, physically proximate to their IKiribati companions. The poses and garments of the subjects signify a relief of the initial anxiety of their interaction.

As the epigraph to this essay suggests, Stevenson ultimately leaves behind the fluid space of travel, yet her interior transformations distinguish her even after disembarking in Noumea. Unlike Grimshaw, Stevenson's self-fashioning embraces physical intimacy as a form of pleasurable play. Fanny and her husband never fully cross over into the realm of the unacceptable: their monogamous heteronormativity is never questioned, their cross-racial friendships are class-appropriate, and even on the very racially mixed ship on which they were traveling, they maintain the relatively esteemed status of paying passengers. They do not 'go native', as beachcombers were so often accused of doing. As suggested in Grimshaw's critique, to 'go native' was to subject oneself to being less-than-native, as it meant refusal of the productivity of the colonial project that had as one purported intention (of many) to raise the status of the Indigenous population. Indeed, beachcombers were particularly liminal and potentially threatening figures for both Westerners and Indigenous populations, as Caroline Ralston and Ian Campbell have insightfully discussed.[47] Fanny and her husband are nevertheless 'bad colonists' as described by Nicholas Thomas and Richard Eves: rather than actively and unproblematically embracing colonization, Stevenson's discussion of the impact of the Western imperial project in the Pacific is ambivalent and recognizes that colonialism plays out in often destructive ways.[48] As Frederick Cooper and Ann Stoler remind us, 'colonial regimes were neither monolithic nor omnipotent', and indeed Stevenson's discussions of the variety of social roles occupied by both whites and Islanders reveals an understanding of the complex texture of the fabric of empire.[49]

Overall, Stevenson's narrative is marked by a particularly American framework. Having led an unconventional existence involving a number of boundary crossings, Stevenson perhaps experienced a greater degree of social mobility than did Grimshaw. Additionally, the years between Stevenson's original journey of 1890 and the subsequent publication of her book in 1914 mark a key historical period of American colonial expansion in the Pacific Islands. Hawaii had been annexed by the USA in 1898, only a few years prior to her book's publication. Also in 1898, the Spanish-American War secured the Philippines and Guam as US territories, and in 1899 the Treaty of Berlin divided Samoa between Germany and the USA, creating the territory of American Samoa, which remains under US control. America's interest in a number of other island groups in the Eastern Pacific, including the Society Islands and the Marquesas IsLands, extends to much earlier in the nineteenth century, yet the late nineteenth century was marked by the presence of an expanded, more permanent, and more politically and socially dominant American presence in the Islands. Stevenson's unexpected and unconventional experiences and critique of the social and cultural impact of previous colonialists (primarily French and British) also mark the Pacific Islands as the potential site for expansion by new colonial agents. Fueled by this presence, and by the success of earlier accounts such as Herman Melville's Typee (1846), the American interest in this area expanded, creating a new market for texts such as hers. Overall, Stevenson's text is not only a product of her own experience, but of the American presence in the Pacific Islands at the turn of the twentieth century and of increased American political and popular interest in these Islands. 


\section{IRREGULAR TEXTS: READING GRIMSHAW AND STEVENSON}

Accepting travel writings as unmitigated 'truth' is certainly problematic; it might be more appropriate to consider them as a dramatized narrative of a series of subjective impressions of people and place. Nevertheless, travel narratives probably were (and often continue to be) perceived as truth by their audiences. The intimacy of their encounters becomes, through the pleasures of reading and looking, the intimate experience of their readers. Discerning audience response is, of course, always a tricky business; I only suggest possibilities here rather than argue for a certain monolithic experience. That both books were originally published as illustrated hardbacks, appropriate for a personal library, certainly infers a middle- to upper-class readership. Grimshaw's work was produced by a London publisher (Hutchinson) and Stevenson's by an American one (Charles Scribner's Sons); one can infer from this primarily localized audiences. What is more difficult to determine is the primary gender of their audience. The reading of travel literature suggests both the desire to experience and also potential for experiencing: while not necessarily realized, the possibility of doing so is promised by the interaction with the text. Susan Bassnett argues for the 'strong emphasis on the personal' in women's travel writing; for the female reader, gender identification with the author would enable an enhanced experience of the text. [50] Although women certainly read earlier travel writing from the Pacific, the gender identification between reader and author enabled by women reading Stevenson and Grimshaw furthered the experience of the 'real' produced through travel writing. The photographs in the two texts, in heightening the experience of difference for the traveling authors by making visual the moments of their journeys they found particularly extraordinary, curious, or weird, further enhance the truth value of the two texts and thereby, the immediacy of experience they promise for an audience.

In different ways, both Grimshaw's and Stevenson's texts present their readers with the potential for adventure as well as the potential for mobility. Most of all, The Cruise of the 'Janet Nichol' and In the Strange South Seas created an imaginary of Polynesia for an entirely new audience. Bassnett suggests that the difference between women's and men's travel writing lies in the indistinct itself: in 'differences in emphasis, in selection of material, in the relationship between the traveler and the putative reader'.[51] Through their combination of pleasured narrative (with the promise of undoable danger) with the visual dimension of the photograph, Stevenson and Grimshaw produce texts that are of immediate appeal to their key readership: the bourgeois white woman living in the USA or Britain. Unlike the harsh realities of the American or African colonial frontier, or indeed the toils experienced by missionary women and traders' wives, the bourgeois adventurer in the Pacific experiences the leisure of travel while maintaining the guise of productivity by recording the events that occur around them. Stevenson's and Grimshaw's constructions of the intimate, domestic, interiorized spaces of empire playa key role in the reception of the Pacific Islands by a popular anglophone readership at the turn of the twentieth century. 


\section{ACKNOWLEDGEMENTS}

I would like to thank Kristen Cheney, Riet Delsing, Gillian Goslinga, Stacy Kamehiro, and Colin Ramsey for their insightful comments on various drafts of this essay. At Women's History Review, Belinda Davis and two anonymous readers provided additional guidance and suggestions. Photographs from Fanny Stevenson's text are reprinted with kind permission of the Writer's House Museum, Edinburgh; I extend my thanks to Elaine Greig for her assistance with this matter. The office of the Dean of the College of Fine and Applied Arts at Appalachian State University kindly covered the reproduction costs.

\section{NOTES}

[1] See F. Stevenson (1914) The Cruise of the 'Janet Nichol' among the South Sea Islands: a diary by Mrs. Robert Louis Stevenson (New York: Charles Scribner's Sons) and B. Grimshaw (1907) In the Strange South Seas (London: Hutchinson).

[2] See M. Strathern (1981) Culture in a Netbag: the manufacture of a subdiscipline in anthropology, Man, 16, pp. 66S-688, for the inherent problems of assuming a sense of universal 'womanhood' when writing women's ethnography.

[3] See 1. Bird (1882) The Hawaiian Archipelago: six months among the palm groves, coral reefs and volcanoes of the Sandwich Islands, Sth edn (London, J. Murray) and C. Gordon Cumming (1882) A Lady's Cruise on a French Man-of-War (Edinburgh: W. Blackwood).

[4] R. Jolly (2004) Introduction, in Roslyn Jolly (Ed.) The Cruise of the 'Janet Nichol' among the South Sea Islands: a diary by Mrs. Robert Louis Stevenson (Seattle: University of Washington Press), pp. 13-47 (p. 47).

[5] Grimshaw, In the Strange South Seas, p. iii.

[6] A significant body of scholarship has emerged to address the connections between photography, tourism, and the Western colonial project in the Pacific Islands. For several key examples, see A. Nordstrom (1991) Early Photography in Samoa: marketing stereotypes of paradise, History of Photography, IS(4), pp. 272-286; C. Blanton (Ed.) (199S) Picturing Paradise: colonial photography of Samoa, 1875 to 1925 (Daytona Beach, FL: Daytona Beach Community College Trustees); M. Hayes (2004) Photography and the Emergence of the Pacific Cruise: rethinking the representational crisis in colonial photography, in E. Hight \& G. Sampson (Eds) Colonialist Photography: imag(in)ing race and place (London and New York: Routledge), pp. 172-187; and P. Johnston (2004) Advertising Paradise: Hawai'i in art, anthropology, and commercial photography, in Hight \& Sampson (Eds) Colonialist Photography, pp. 188-22S. See also Joyce Kelley's recent analysis of several early twentieth-century women travelers who used photographs to illustrate their travel accounts to Africa and the Middle East. J. Kelley (200S) Increasingly 'Imaginative Geographies': excursions into otherness, fantasy, and modernism in early twentieth-century women's travel writing, !NT: Journal of Narrative Theory, 3S(3), pp. 3S7372. 
[7] As Jordana Pomeroy notes, their ease in portability made watercolors the most common medium for women to use when visually recording their travels. See J. Pomeroy (200S) 'We Got Upon our Elephant and Went Out After Subjects': capturing the world in watercolor, in J. Pomeroy (Ed.) Intrepid Women: Victorian artists travel (Aldershot: Ashgate), pp. 39-S0 (p. 39). I would add that women in the nineteenth century were more often trained in watercolors than in photography or oil painting. Indeed, in the same volume only Jeff Rosen's essay on Julia Margaret Cameron's work in India explores the photographic record of European women in the colonies. See J. Rosen (200S) Cameron's Colonized Eden: picturesque politics at the edge of the empire, in Pomeroy (Ed.) Intrepid Women, pp. 109-128. Although outside the boundaries of my immediate concerns in this essay, Cameron's photographs make an intriguing juxtaposition with Grimshaw's and demonstrate the need for further consideration of British women's photography from the colonial realm.

[8] K. Segal (2004) Intersections: women's travel and theory, in K. Segal (Ed.) Gender, Genre, and Identity in Women's Travel Writing (New York: Peter Lang), pp. 1-14 (p. 2).

[9] S. Mills (1991) Discourses of Difference: an analysis of women's travel writing and colonialism (London and New York: Routledge), p. 30.

[10] J M. Pratt (1992) Imperial Eyes: travel writing and transculturation (London and New York: Routledge), pp. IS9-160.

[11] Mills, Discourses of Difference, p. 3.

[12] A. Stoler (2002) Carnal Knowledge and Imperial Power: race and the intimate in colonial rule (Berkeley: University of California Press), p. 43.

[13] C. McEwan (2000) Gender, Geography and Empire: Victorian women travellers in West Africa (Aldershot: Ashgate), pp. 12-13.

(14] S. Gardner (198S) For Love and Money: Beatrice Grimshaw's passage to Papua (PhD thesis, Rhodes University), pp. S-6.

[15] Much of the writing on Grimshaw is biographical; for two exceptions see M. Jolly (1997) From Point Venus to Bali Ha'i: eroticism and exoticism in representations of the Pacific, in L. Manderson \& M. Jolly (Eds), Sites of Desire, Economies of Pleasure: sexualities in Asia and the Pacific (Chicago: University of Chicago Press), pp. 99-122, and C. McCotter (2006) Islanders, Tourists and Psychosis: doing time in Beatrice Grimshaw's travel brochures, Journal of Tourism and Cultural Change, 4(1), pp. 1-18.

[16] S. Gardner (1987/88) A 'Vert to Australianism': Beatrice Grimshaw and the bicentenary, Hecate, 13, pp. 31-68 (p. 48).

[17] Ibid., p. 35.

[18] D. Oliver (1989) The Pacific Islands, 3rd edn (Honolulu: University of Hawaii Press), p. 72.

[19] Ibid. 
[20] For a more extensive discussion of the development of plantation economies and labor relations in specific areas, see D. Denoon (1997) Land, Labour and Independent Development, in D. Denoon et al. (Eds) The Cambridge History of the Pacific Islands (Cambridge: Cambridge University Press), pp. IS2-184.

[21] Monica Anderson has noted British women's frequent (if complicated) complicity with the goals of empire in their travel writing, further stressing Grimshaw's connection with the broader literature of empire. See M. Anderson (2006) Women and the Politics of Travel, 1870-1914 (Madison, NJ: Fairleigh Dickinson University Press).

[22] Stoler, Carnal Knowledge and Imperial Power, p. 35.

[23] Ibid., p. S7.

[24] As a studio portrait of (relatively) professional quality, it is unlikely that Tahitian Native is Grimshaw's own photograph. Tahitian Beauty, an exterior shot, more closely resembles in style and content the snapshot aesthetic of most of the other photographs in the text.

[25] Grimshaw, In the Strange South Seas, pp. 54-5S.

[26] Ibid., p. 262.

[27] Ibid., p. 13.

[28] Ibid., p. 9.

[29] M. Jolly, 'From Point Venus to Bali Ha'i', p. 110.

[30] Grimshaw, In the Strange South Seas, p. IS.

[31] Ibid., pp. 158-1S9.

[321 Ibid., p. 256.

[33] R. Jenkins (2004) The Gaze of the Victorian Woman Traveler: spectacles and phenomena, in K. Siegel (Ed.), Gender, Genre, and Identity in Women's Travel Writing (New York: Peter Lang), pp. 15-30 (p. 17).

[34] Ibid., p. 19.

[35] I. Ghose (1998) Women Travellers in Colonial India: the power of the female gaze (Delhi: Oxford University Press), pp. 8-9.

[36] For a biographical account of Stevenson, see A. Lapierre (1995) Fanny Stevenson: a romance of destiny, trans. C. Cosman (New York: Carroll \& Graf).

[37] Stevenson, The Cruise of the 'Janet Nichol', p. 21.

[38] As with Grimshaw, there has been little critical analysis of Stevenson's work, yet recently two scholars have suggested new avenues for consideration of Stevenson as an important, but 
previously overlooked, t1gure in Pacitlc travel writing. Vanessa Smith has stressed that Stevenson's writing from the Pacific 'offers a commentary on the gendering of travel as experience and as discourse, making explicit the different things th at men and women saw in crossing cultures'. V. Smith (2000) Fanny Van del" Grift Stevenson: cannibal fashions, in J. Lamb, V. Smith \& N. Thomas (Eds) Exploration and Exchange: a South Seas anthology, 16801900 (Chicago: University of Chicago Press), pp. 311-316 (p. 312). Roslyn Tolly has edited a new edition of Stevenson's book; in her introduction, Jolly argues that Stevenson's writings give insight into the role of women at this historical moment, both herself as a white women and of the many women and girls she encounters. See Tolly, Introduction. lowe a debt to both of these scholars and hope that their work is only the beginning of a fruitful conversation on Stevenson's place in South Pacific literature and history.

[39] Jolly, Introduction, p. 34.

[40] Stevenson, The Cruise of the 'Janet Nichol', p. 27.

[41] Ibid., p. 35, note I.

[42] Ibid., p. 42.

[43] These types of images are found throughout the European colonial world. For a number of examples from the Pacific, including the reinterpretation of these images by Indigenous scholars, see J. Annear (Ed.) (1997) Portraits of Oceania (A11 Gallery of New South Wales).

[44] Stevenson, The Cruise of the 'Janet Nichol,' p. 40.

[45] Ibid., p. 4.

[46]lbid., p. 5.

[47] See C. Ralston (1978) Grass Huts and Warehouses: Pacific beach communities of the nineteenth century (Honolulu: University Press of Hawaii) and I. Campbell (1998) 'Gone Native' in Polynesia: captivity narratives and experiences from the South Pacific (Westport, CT: Greenwood Press).

[48] See N. Thomas \& R. Eves (1999) Bad Colonists: the South Seas letters of Vernon Lee Walker and Louis Becke (Durham, NC: Duke University Press).

[49] F. Cooper \& A. Stoler (1989) Introduction. Tensions of Empire: colonial control and visions of rule, American Ethnologist, 16(4), pp. 609-621 (p. 609).

[50] S. Bassnett (2002) Travel Writing and Gender, in P. Hulme \& T. Youngs (Eds) The Cambridge Companion to Travel Writing (Cambridge: Cambridge University Press), pp.225-241 (p.231).

[51] Ibid., p. 240. 